Haya: The Saudi Journal of Life Sciences

Abbreviated Key Title: Haya Saudi J Life Sci ISSN 2415-623X (Print) |ISSN 2415-6221 (Online) Scholars Middle East Publishers, Dubai, United Arab Emirates Journal homepage: http://scholarsmepub.com/haya/

Review Article

\title{
Impact of Climate Change on Honey Bee Population and Diseases with Special Reference to Fiji Islands
}

Sachchida Nand Rai ${ }^{*}$ Kalivoa Ravuiwasa

Department of Crop and Plant Protection College of Agriculture, Fisheries and Forestry, Fiji National University, P.O. Box 1544, Nausori, Fiji Islands

DOI: $10.36348 /$ SJLS.2019.v04i10.001 $\quad$ | Received: 21.10.2019| Accepted: 28.10.2019| Published: 11.11 .2019

*Corresponding author: Sachchida Nand Rai

Abstract

Honey bees are crucial in maintaining the biodiversity by pollinating number of plant species whose fertilization requires an obligatory pollinator. The European honey bee, Apis mellifera used by the bee keepers in Fiji is found as most economically valuable pollinator and has shown great adaptive potential against the variation in climate. The species is found almost on every agricultural crop worldwide and in highly diverse climates. In context to climate change, the variability in life history of Apis mellifera regards to temperature and the environment shows that the species possesses genetic variability; this could give rise to the selection of development cycles suited to new climatic conditions. Taking the above into consideration, it is to be examined the potential impact of climate change on honey bee behaviour, its physiology and distribution, as well as on the evolution of the honey bee's interaction with diseases.

Keywords: Adaption, Apis mellifera, biodiversity, honey bee, disease, environment.

Copyright @ 2019: This is an open-access article distributed under the terms of the Creative Commons Attribution license which permits unrestricted use, distribution, and reproduction in any medium for non-commercial use (NonCommercial, or CC-BY-NC) provided the original author and source are credited.

\section{INTRODUCTION}

At every bite of food, one must thank either a bee or a bird or an insect or a mammal for their pollination services. From the data of 200 countries, $35 \%$ of world food production depends on pollinators. Of 115 crops, 90 crops entirely depend on bee pollinators. Honey bees of Apis genus are distributed throughout the world in highly diverse climate. The Apis mellifera species whose distribution range extends to Sub-Saharan Africa, northern Europe and central Asia. The other honey bee species of Apis genus are distributed around Asia, particularly tropical south-east Asia [1].

A change in climate conditions is bound to have an impact on the survival of honey bee species that are closely associated with their environment. Migration and changes in their life cycle and behaviour could help them to survive in new biotypes. Honey bee also needs to adapt to a whole array of predators, parasites and pathogens surrounding them. Climate change could create new opportunities for establishing honey bee in regions or habitats. Climate change may lead to a sharp increase in rate of extinction [2].

The honey bee: an economically valuable species

The long-term survival of farming worldwide relies in part on insect pollinators. In monetary terms, they contribute an estimated US\$ 117 billion per year [3]; around 35\% of agricultural crops depend directly on pollinators [4] and $84 \%$ of cultivated plant species are involved with the activity of these insects [5]. The European honey bee, Apis mellifera, is the most economically valuable pollinator of agricultural crops worldwide [6]. Honey bees are also crucial for maintaining biodiversity because they pollinate numerous plant species that require an obligatory pollinator for fertilization [7,8]. Climate change could destabilize relationships between flowers and pollinators, and pollinators will need to be protected to ensure that they continue their pollination function, which is so important for the economy and for the ecological balance.

\section{Bee diseases and parasites}

Numerous predators, parasites (mites) and pathogens (protozoa, bacteria and viruses) prey upon the honey bee.

\section{Mites}

The honey bee tracheal mite, Acarapis woodi, is a parasite of Apis mellifera. It lodges itself in the trachea of worker bees, where it breeds, and eventually suffocates them [9]. Although it was a pest in the 20th Century, the tracheal mite is now no longer a major problem for world apiculture. 
The Varroa mite, Varroa destructor, is a pest that destroys colonies of Apis mellifera worldwide, with the exception of Australia where it is not yet present. Scientists tend to attribute honey bee mortality largely to the Varroa mite. Originally a parasite of the Asian honey bee, Apis cerana, it was transferred to the European honey bee, Apis mellifera, in the midtwentieth century by exchanges of genetic material among many countries [10]. Left untreated, colonies infested with the Varroa parasite die after two to three years. It is impossible to eradicate this parasitic infection.

Varroa mites help to diminish the honey bee's immune response and encourage the development of viral infections [11]. They are also active vectors in the transmission of viruses and bacteria $[12,13]$.

The problems with Varroa parasite control are typical of those encountered in curbing any insect pest population. Varroa are becoming resistant to the acaricides used by beekeepers to control them [14].

\section{Protozoa}

Nosema apis is a microsporidian that attacks the midgut wall of adult honey bees. The disease can develop with no visible symptoms or manifest itself as a weakening of the colony, possibly ending in death. The disease tends to emerge mainly in early spring following long, wet winters. During winter, honey bees are prevented from going outside and drop their excrement inside the hive, forming a source of contagion for other bees. After this, the disease spreads rapidly. Even though Nosema apis exhibits signs common with other diseases, the disease can be identified by certain signs observable when inspecting the colony and in the laboratory [15].

\section{Bacteria}

The bacteria pathogenic to honey bees attack the brood. American foulbrood, a disease that has been known since ancient times, is caused by Bacillus larvae. This serious, highly contagious disease occurs across globally [15].

European foulbrood is caused by Melissicoccus pluton, in association with other bacteria.It tends to gain a foothold in weakened colonies in spring and at first is benign. A supply of pollen from outside the nest is usually all colonies need to overcome the disease, although heavy losses have been reported in the past [15].

At present, only antibiotics are effective in treating these protozoa and foulbroods, but they are no longer authorized because of the hazard of residues in honey.
Viruses

Eighteen different viruses have been identified in honey bees of the Apis genus. Some of these viruses are highly anecdotal, while others are latent and can be extremely prolific among the bees in our hives without causing any noticeable signs [16]. For reasons as yet unknown, these viruses can become highly pathogenic to honey bees, causing trembling and paralysis that are observable at the colony entrance. This is the case with chronic paralysis virus (CPV) and acute paralysis virus (APV). It is not yet known how these viruses act to kill bees. No treatment exists to control such viruses, which can weaken or kill the colony. These pathologies can be stemmed by a supply of quality pollen from foraging bees. Varroa weakens the bee's immune system and encourages viral growth [17].

\section{Impact of climate change on honey bees}

Climate change can impact on honey bees at different levels. It can have a direct influence on honey bee behaviour and physiology. It can alter the quality of the floral environment and increase or reduce colony harvesting capacity and development. It can define new honey bee distribution ranges and give rise to new competitive relationships among species and races, as well as among their parasites and pathogens. Beekeepers will also be obliged to change their apiculture methods. They will favour moving their hives to new foraging areas and importing foreign races to test their value in the new environments.

\section{Impact of climate change on honey bee behaviour, physiology and distribution}

The European honey bee, Apis mellifera, has the potential to adapt to hot climates. For instance, Apis mellifera sahariensis is found in the oases of the Sahara, where it has adapted to local bloom (such as palm flowers) and extreme heat [1]. In the USA, honey bees can develop in the Arizona Desert. The survival requirement for these bees is a supply of water, which they use in large quantities to raise their larvae and to regulate the brood temperature to between $34^{\circ} \mathrm{C}$ and $35^{\circ} \mathrm{C}$. In an arid environment, desert flowers are unable to provide the bees with enough water and they die. According to climate change predictions, desert regions will become even drier, leading to the disappearance of oases and their honey bees. Apis mellifera sahariensis is highly unlikely to migrate naturally to more favourable desert areas because oases are very isolated and not conducive to long-distance migration or swarming. It is therefore vital to envisage conservation measures to transfer this bee to zones favourable to its development, lest we lose this ecotype that is so valuable for world biodiversity.

Climate change can influence the honey bee development cycle. It is generally agreed that each race of honey bees develops at its own rate. In cool regions, honey bees spend the winter clustered in a tight ball and use their honey stores to provide them with the energy 
they need to survive until spring. The honey bee's capacity to accumulate energy reserves and to manage the colony's development exerts significant adaptive pressure. In the spring, when the weather becomes more clement, the queen starts to lay eggs and the colony develops and increases the size of the worker population. A cold snap lasting several weeks may occur during which the honey bees are unable to harvest. The large size of the honey bee population causes such a rapid depletion of stores that the colony can die of starvation. Hybrids bees (crosses of several races by bee breeders) have not been bred to build up food stores, the queen does not adjust her egg-laying and the workers do not adjust their larvae-rearing, with the result that the bees are unable to survive without the assistance of a beekeeper to provide them with unlimited supplies of sugar solution. The variability of the honey bee's life- history traits as regards temperature and the environment shows such plasticity and genetic variability that this could give rise to the selection of development cycles suited to new climatic conditions.

Bees adjust their behaviour to weather conditions. They do not go out when it rains and, in extremely hot weather, they gather water to keep the colony cool.

\section{Would climate-induced changes in flora provide honey bees with the conditions for viability?}

Climate influences flower development and nectar and pollen production, which are directly linked with colonies' foraging activity and development [18]. Bees must build up sufficient honey stores to enable them to survive the winter. The nurse worker bees must consume enough pollen to feed the larvae through their pharyngeal glands. A major effect of climate change on honey bees stems from changes in the distribution of the flower species [19] on which the bees depend for food. We are aware of the impact that rain can have on honey harvesting by bees. For instance, when acacia flowers are washed by rain, they are no longer attractive to honey bees as it dilutes their nectar too much. Likewise, an overly dry climate will reduce the production of flower nectar for honey bees to harvest: lavender flowers produce no nectar when the weather is too dry, which makes harvesting by bees a largely hypothetical matter. In extreme situations, honey bees can die of starvation unless the beekeeper is vigilant.

The honeydew produced by stinging insects from certain plant species is also climate-dependent. In Alsace, very special conditions are required for the development and growth of balsam fir aphid populations, whose honeydew is highly attractive to honey bees (Jean-Prost and Le Conte, 2005). On the other hand, certain types of honeydew cause dysentery in honey bees.
The food shortages stemming from an excessively dry climate, which reduces pollen production and impoverishes its nutritional quality, are currently the subject of much debate [20]. Honey bees that are born in autumn spend the entire winter in the hive and form the backbone of the colony in spring. A pollen diet is very important for rearing the future workers [21]. A pollen shortage induced by autumn drought will have the effect of depriving bees in winter, weakening their immune system and making them more susceptible to pathogens, and shortening their lifespan.

\section{Diseases and parasites: changes in disease profiles and incidence}

\section{Different diseases in different parts of the world}

\section{Current disease profiles and potential changes in distribution arising from climate change}

Some known pathogens are distributed worldwide. They include: Varroa destructor in the case of Apis mellifera; bacteria that cause American foulbrood; Nosema apis and numerous viruses affecting Apis mellifera. These pathogens tend to have different haplotypes of varying virulence. Climate change can encourage the transfer of these haplotypes to honey bee populations.

Other pathogens or haplotypes have more limited distribution ranges, such as Tropilaelaps, which to date have been found only in Asia [9]. Climate change will lead to movements of honey bees of different species and races, bringing them into contact with pathogens with which they have never co-evolved, as has occurred with Varroa destructor and Apis mellifera. In the space of a few decades last century, two extremely homogeneous haplotypes of this honey bee parasite were sufficient to invade virtually the entire Apis mellifera distribution range [22]. History therefore shows that such encounters can be catastrophic and that honey bees will need human assistance to survive. Honey bee movements may be spontaneous and linked to changes in geographical distribution, or the result of exchanges of bees among beekeepers.

There could be changes in the geographical distribution of diseases whose expression depends on climatic factors. This has happened with chalkbrood disease, which is caused by the fungus Ascosphera apis, which develops mainly in a humid environment.

\section{Consequences for bee health and socioeconomic impact}

Honey bees will require human protection, if only because of their importance for agricultural production and markets. It seems clear that bees will come into contact with new pathogens. The high mortality rate and colony collapses that we are currently seeing demonstrate the fragility of honey bee 
populations worldwide. As has been the case with the Varroa threat to Apis mellifera, our honey bees will need to be aided with medicines and appropriate control methods to prevent them from becoming extinct.

\section{Climate change can facilitate the emergence of new invasive species}

Numerous examples have revealed the fragility of the host-parasite balance and shown that even slight climate changes impact on the establishment of invasive species that are currently at the fringes of the honey bees' distribution range. The situation of honey bees can also evolve when predators colonise new areas. A stark example is that of the bee-eater, a magnificent bird that feeds on Hymenoptera and bees. The bee-eater originated in the Mediterranean region but has extended its distribution range, causing only minimal harm to beekeepers so far. In France it is now found north of the Loire. A second example is an apiary pest, the small hive beetle (Aethina tumida), which originated in South Africa and develops on the weakest honey bee colonies. The parasite was imported into the USA, probably on citrus fruit on which the beetle can also develop. It has compounded the problems of American beekeepers, especially in hot and humid regions. The cold climate has halted the beetle's northward progression. Climate change will promote the extension of its distribution range. Measures have been taken to prevent this insect pest from being imported into Europe, where it is considered a potential hazard.

\section{Socioeconomic aspects}

Not only bees, but beekeepers too, will need to adapt to changes in climate and flora. This means that some regions that are now hostile to beekeeping will become of interest to beekeepers, whilst other foraging areas will have to be abandoned. A decisive factor in beekeepers' choices will be the adaptiveness of honey plants to climate change. Beekeepers will also need to adapt their bees to climate change, abandoning local ecotypes or races in favour of better-adapted honey bees. This means that measures must be envisaged to conserve honey bee races and ecotypes to limit the loss of bee biodiversity. An appealing technique is sperm cryopreservation.

\section{Recent cases of mortality}

Since 1995, we have been seeing heavy mortality among Apis mellifera worldwide. The consensus among researchers is that a combination of factors is responsible for this honey bee mortality. Pesticides kill many colonies every year. New pathogens have been added to the already long list of honey bee diseases. However, researchers agree that the bees' environment and stress, both of which are influenced by climate change, have been decisive factors in this heavy mortality [23, 24]. There appear to be strong interactions between diseases, pesticides, environment and climate. Climate change has an action on each of these factors. To understand the effect of climate change on the evolution of honey bee populations, each of these factors will need to be taken into account.

\section{CONCLUSION}

Widespread mortality in the Apis mellifera honey bee worldwide aptly demonstrates the fragility of this species, whose survival relies on an increasingly hostile environment. The reasons given to explain this phenomenon include pesticide use, new diseases, stress and a combination of these factors. As a result, climate change will shift the balance between the honey bee, its plant environment and its diseases. The honey bee has shown a great capacity to colonise widely diverse environments and its genetic variability should enable it to adapt to such climate change. However, the fear is that climate-induced stress will in future compound the various factors already endangering the species in certain regions of the world. If humans modify the honey bee's environment, they also have a duty to take conservation measures to prevent the loss of this rich genetic diversity of bees. To understand the factors favouring the extinction of honey bees, it will be necessary to conduct fundamental research aimed at ascertaining the causes of mortality, as well as the effect of human-induced environmental change. Environmental impact studies in the field, as well as the use of modern genomics methods made possible by the recent sequencing of the bee genome, are expected to play a prominent role in discovering the vital stress factors for these species.

\section{REFERENCES}

1. Ruttner, F. (1988). - Biogeography and taxonomy of honeybees. Springler, New York.

2. Slathia, I., \& Tripathi, N. K. (2016). Impact of Climate Change on Honey-Bee Populations and Diseases. Published by Research Trend, Website: www. biobulletin. com, 2(1), 40-42.

3. Costanza, R., d'Arge, R., De Groot, R., Farber, S., Grasso, M., Hannon, B., ... \& Raskin, R. G. (1997). The value of the world's ecosystem services and natural capital. nature, 387(6630), 253.

4. Klein, A. M., Vaissiere, B. E., Cane, J. H., SteffanDewenter, I., Cunningham, S. A., Kremen, C., \& Tscharntke, T. (2006). Importance of pollinators in changing landscapes for world crops. Proceedings of the royal society B: biological sciences, 274(1608), 303-313.

5. Williams, I. H. (1996). Aspects of bee diversity and crop pollination in the European Union.

6. Johnson, R. (2007, June). Recent honey bee colony declines. Library of congress washington $\mathrm{dc}$ congressional research service.

7. Allen-Wardell, G., Bernhardt, P., Bitner, R., Burquez, A., Buchmann, S., Cane, J., ... \& Inouye, D. (1998). The potential consequences of pollinator declines on the conservation of biodiversity and stability of food crop yields. Conservation biology, 8-17. 
8. Michener, C. D. (2000). The Bees of the World Johns Hopkins University Press. Baltimore, London.

9. Sammataro, D., Gerson, U., \& Needham, G. (2000). Parasitic mites of honey bees: life history, implications, and impact. Annual review of entomology, 45(1), 519-548.

10. Oldroyd, B. P. (1999). Coevolution while you wait: Varroa jacobsoni, a new parasite of western honeybees. Trends in Ecology \& Evolution, 14(8), 312-315.

11. Gregory, P. G., Evans, J. D., Rinderer, T., \& De Guzman, L. (2005). Conditional immune-gene suppression of honeybees parasitized by Varroa mites. Journal of Insect Science, 5(1).

12. Yang, X., \& Cox-Foster, D. L. (2005). Impact of an ectoparasite on the immunity and pathology of an invertebrate: evidence for host immunosuppression and viral amplification. Proceedings of the National Academy of Sciences, 102(21), 74707475.

13. Yang, X., \& Cox-Foster, D. (2007). Effects of parasitization by Varroa destructor on survivorship and physiological traits of Apis mellifera in correlation with viral incidence and microbial challenge. Parasitology, 134(3), 405-412.

14. Milani, N. (1999). The resistance of Varroa jacobsoni Oud. to acaricides. Apidologie, 30(2-3), 229-234.

15. Prost, P. J., \& Le Conte, Y. (2005). Apiculture, connaitre l'abeille-conduire le rucher. Lavoisier, Paris, 382.

16. Tentcheva, D., Gauthier, L., Zappulla, N., Dainat, B., Cousserans, F., Colin, M. E., \& Bergoin, M. (2004). Prevalence and seasonal variations of six bee viruses in Apis mellifera L. and Varroa destructor mite populations in France. Appl. Environ. Microbiol., 70(12), 7185-7191.

17. Chen, Y., Evans, J., \& Feldlaufer, M. (2006). Horizontal and vertical transmission of viruses in the honey bee, Apis mellifera. Journal of invertebrate pathology, 92(3), 152-159.

18. Winston, M.L. (1987). The biology of the honey bee. Harvard University Press, Cambridge, Massachusetts.

19. Thuiller, W., Lavorel, S., Araújo, M. B., Sykes, M. T., \& Prentice, I. C. (2005). Climate change threats to plant diversity in Europe. Proceedings of the National Academy of Sciences, 102(23), 82458250 .

20. Stokstad, E. (2007). The case of the empty hives. Science, 316(5827), 970-972.

21. Mattila, H. R., \& Otis, G. W. (2006). Influence of pollen diet in spring on development of honey bee (Hymenoptera: Apidae) colonies. Journal of economic entomology, 99(3), 604-613.

22. Solignac, M., Cornuet, J. M., Vautrin, D., Le Conte, Y., Anderson, D., Evans, J., ... \& Navajas, M. (2005). The invasive Korea and Japan types of Varroa destructor, ectoparasitic mites of the Western honeybee (Apis mellifera), are two partly isolated clones. Proceedings of the Royal Society B: Biological Sciences, 272(1561), 411-419.

23. Oldroyd, B. P. (2007). What's killing American honey bees?. PLoS biology, 5(6), e168.

24. Pettis, J., Vanengelsdorp, D., \& Cox-Foster, D. (2007). Colony collapse disorder working group pathogen sub-group progress report. American Bee Journal, 147(7), 595-597. 